\title{
A Brief Analysis on the Application of Lexical Approach in English Reading and Writing Teaching in Independent Colleges
}

\author{
Weijie Kong \\ Dianchi College of Yunnan University, Kunming, 650228
}

Keywords: lexical approach, College English, reading and writing teaching, application

\begin{abstract}
With the deepening of education reform, lexical approach is more and more widely used in English teaching. At present, it has achieved good teaching effects and promotes the improvement of students' English application ability. This paper focuses on the application of lexical approach in reading and writing teaching of College English in independent colleges.
\end{abstract}

\section{Introduction}

With the continuous deepening of education reform, teaching mode in classroom has been constantly updated with the progress of the times. In addition, a variety of teaching patterns have gradually gained good teaching effects. In English teaching, because of complex and abstract contents of English knowledge, students are often unable to understand them fully so that teachers' teaching effects are not ideal. At the same time, reading and writing teaching of College English has always been the focus of English teaching. Only with students' improvement of reading and writing ability, can they effectively apply English in practice. With the gradual deepening of the application of Lexical Approach, English Teaching has made efficient improvements and deepened students' understanding and memory of English knowledge. However, it is a long process to apply Lexical Approach in domestic and there is insufficient related teaching experience. Therefore, teachers must strengthen the analysis and discussion of Lexical Approach, and constantly explore related experience, so as to effectively play the real role of Lexical Approach.

\section{Connotation of Lexical Approach}

In the 90s of last century, Lexical Approach was firstly propose, in which lexical chunk was mainly a kind of relatively special image of multi-word language. Usually, it mainly appeared in a fixed or semi-fixed module. In human's memory, lexical chunk exists as a whole and could not be extracted directly. Lewis, who propose Lexical Approach, believe that in the course of language learning, the main module is lexical chunk, not just a simple combination of words and grammar. In addition, he holds that sentence pattern is composed by connecting lexical chunks together in accordance with relevant grammatical rules, but not formed by a simple connection of words and grammar. As for the new mode of Lexical Approach, its application in reading and writing teaching of College English can better express related grammar and sentence patterns in the form of lexical chunks so as to deepen students' understanding and memory. The classification of English lexical chunks mainly includes the following categories:

Individual words and poly words are the first category. There is no obvious difference between the meaning of individual word with its traditional meaning. The definition and classification of poly word are similar to that of phrase in the traditional English teaching process, mainly referring to the collocation of fixed two or three words. Usually, when the composition of expressions is changed or divided, the meaning will also vary. For example, common words such as on the way, by the way, on the one hand, on the other hand and other phrases can be grouped into a category of poly words.

Generally speaking, collocations in English are used more colloquially, and their definition refers to the combination of words with high appearing frequency in natural language. Collocations often appear in daily life, belonging to same kind of conventional words. 
In the process of actual English communication, fixed expression of some sentences, such as some proverbs, is applied frequently in certain language sets according to different dialogues. The application of these fixed expressions must be integrated with actual contexts and modes.

In the application process of semi-fixed expressions, which usually are a few discontinuous structural phrases, they are more flexible than fixed expressions. The specific use of semi-fixed expressions can make English sentences more refined, often appearing in a large number of English oral and written expressions. ${ }^{[1]}$

\section{Major Problems in Reading and Writing Teaching of College English in Independent Colleges}

At present, the main enrollment of students in independent college in China is the third batch of undergraduate students. These students are often weak in basic knowledge, lack accumulation of basic English knowledge, and are in need of independent learning ability. In English teaching, students lack initiatives and usually depend on teachers' explanation. In addition, reading and writing teaching of College English belongs to a public course, for which students' enthusiasm is insufficient. It is generally believed that this kind of course is completed as long as examinations are past, since students are not fully aware of the importance of the ability to listen, speak, read and write. Under this background, there is no enough cultivation of students' ability to read and write English, so the effects of English teaching fail to reach the standard, and students have not really mastered the practical ability of English.

In the current independent colleges, teaching contents of English are often relatively complex and abstract. In the course of classroom teaching, teachers as the main body, explaining the knowledge to students. In this process, students' learning is often too passive to improve their enthusiasm. For a long time, students gradually lose interest in learning English, resulting in a decline in English performance, and dissatisfied comprehensive ability training. At the same time, in the course of English reading and writing teaching, teachers usually take into account the number of students. In order to complete teaching goals as soon as possible, they will not interact with students reasonably, which leads to the dull and boring classroom atmosphere, and unrelieved as well as unhappy learning environment, thus guiding students' declining enthusiasm for learning.

With the development of information age and the deepening of education reform, information technology has been fully applied to teaching. The teaching mode based on multimedia technology has achieved good teaching effects. In English teaching, the use of multimedia technology makes the abstract and complex English contents become more intuitive and vivid which is conducive for students to understanding and remembering. However, in the actual English teaching, teachers often have a low application level of information technology, failing to fully apply information technology to teaching. When using multimedia technology to teach, most teachers only display the knowledge contents on multimedia projection screen in the static form, which is not very different from the traditional teaching mode. In fact, knowledge contents are just transferred from blackboard to the projection screen of the media. In this case, students' reading and writing ability is not effectively trained. ${ }^{[2]}$

Usually, in the course of English reading and writing teaching in independent colleges and universities, the assessment of students' learning situation is usually based on examination results. In general, the examination grades are $70 \%$ of the total results. While, students' performance in class and the completion of their homework only occupy thirty percent of the comprehensive results. In this context, students' enthusiasm for English learning often falls seriously, and it is difficult to achieve the true purpose of reading and writing teaching.

\section{Application Strategy of Lexical Approach in English Reading and Writing Teaching}

In the application of Lexical Approach, improving the accumulation of lexical chunks is the key to teaching. In the teaching of College English in independent colleges, teachers must guide students to improve the accumulation. Only through a large amount of lexical chunks can help 
students to read and write English effectively. In the cultivation course of students' English reading ability, it is necessary to fully understand sentences in order to better grasp key points in the article. However, in English reading, there are different meanings in different contexts. At this time, it is feasible to make use of the accumulation to fully understand contents. When students' ability to write in English is cultivated, more lexical chunks are needed to express the inner meaning better. Therefore, in classroom teaching and daily training, it is necessary to strengthen the training of students' lexical chunks, which are, usually, relatively fixed. In the process of guiding students' memory, teachers should maximize the relationship between lexical chunks and contexts to strengthen the memory of students. It will be a long process to learn English and train abilities to learn, read and write English. Therefore, it will also take a long time in the learning of lexical chunks. Students must be patient in the process and apply them effectively through continuous learning and practice. In addition, students must consider specific application of different lexical chunks in learning. For example, when using them in some situations, it is necessary to firstly make clear the corresponding methods of use, develop the application ability through continuous practice, and then give full play to the learning effect of Lexical Approach.

There is a certain relationship between different lexical chunks, so when teachers use them to teach, they must connect these chunks according to similar characteristics so that students can make a comparison and strengthen their understanding and memory of lexical chunks. Meanwhile, students are also able to expand continuously English vocabulary. In the process of cultivating students' ability to read and write in English, it is required to focus on the cultivation of their coherence ability in lexical chunks knowledge, so as to help them improve the efficiency of composing sentences, enhancing reading comprehension and writing ability. In the actual teaching process, teachers are advised to make use of lexical chunks to create a good teaching atmosphere, in order to better improve students' reading and writing ability. When an article is read and understood, teachers are suggested to connect contents of the article to actual life, thus facilitating students' understanding. In a word, through students' timely induction and summary, it is conducive to helping them strengthen the use of lexical chunks, find the application skills and methods, and then effectively apply them to English reading and writing.

When Lexical Approach is used in English teaching, teachers can divide sentences and paragraphs into different lexical chunks reasonably. At the same time, teachers are capable of explaining more relevant knowledge points and knowledge contents in expanding part for students, so that students' knowledge scope can be effectively widened. In this way, more sentences will be accumulated in classroom, thus improving students' reading and writing ability. At the same time, teachers are supposed to assign some difficult sentences to students in the course of teaching. After a lot of connections, students' ability to break down lexical chunks is to be better trained and the ability to read and write is promoted again.

In the teaching of College English with Lexical Approach, teachers should not only cultivate students' ability to decompose lexical chunks, but also pay more attention to the cultivation of the ability to restore lexical chunks, so that students can better master the mutual conversion between English and Chinese. During cultivating reading and writing ability, only the guarantee of students' bilingual conversion can make their ability to read and write effectively improved. In English reading, students often fail to do English to Chinese translation because they can not understand these contents, resulting in poor reading. Besides, in English Writing, the phenomenon that students often can not express what they want to say in English is quite common. By decomposing and restoring lexical chunks, students' reading and writing ability can be improved.

\section{Conclusion}

To sum up, there are many problems in the teaching of College English in independent colleges leading to poor teaching effects. The application of Lexical Approach makes students better understand and memorize English knowledge. Especially in the training of English reading and writing ability, Lexical Approach can help students fully understand the meaning of article and improve writing ability, so as to improve their English practical ability and promote their all-round 
development.

\section{References}

[1] Ting Mei, Deng Yan. A Brief Analysis of Flipped Classroom Teaching Mode of College English Reading and Writing Course in Independent Colleges [J]. Science and Education Union (the First-10-day-period Edition), 2015 (11): 174-175.

[2] Xiong Neng. On the Application of Lexical Approach in College English Translation Teaching [J]. Overseas English, 2014 (19): 73-74.

[3] Xie Huaizhi. Research On the Application of Lexical Approach in College English Translation Teaching [J]. English Plaza (Academic Research), 2015 (02): 125-126.

[4] Zhang Yanping, Li Fengqing. On the Improvement of English Listening Level by Phonetic Lexical Chunks [J]. Journal of Hubei Institute of Science and Technology, 2013,33 (07): 50-51. 